\title{
The Role of Operating Cash Flow and Accrual Components of earnings in Improving the Predictive Ability of Earnings.
}

Dr/ Ibrahem Mohammed Ali

Associate professor of accounting Faculty of commerce Zagazig university
Dr/ Ramadan Atia Hasan

Associate professor of accounting Faculty of commerce Zagazig university

Shimaa Fathey Mohammed Metwaly

Master's Researcher in Accounting

Faculty of Commerce, Zagazig University

Journal of Business Research

Faculty of Commerce, Zagazig University

Volume 43 - Issue Three, July 2021

link: https: / / zcom.journals.ekb.eg / 


\section{Abstract:}

The prediction of Cash flow is involved in a number of economic decisions, particularly in investment. Previous research conducted in the United States has provided inconsistency in the results of investigating accounting data, cash flow and accrual accounting data in predicting future cash flows. Few researches were detected addressing the prediction of cash flow in an Egyptian context. This research aims to test the ability of accounting earnings versus cash flows and accruals to predict future cash flows for a sample listed firms in the Egyptian stock exchange. To achieve this objective, a sample of $\mathbf{1 0 2}$ firms from 14 different sectors was collected from year 2012 to 2017 (585 observations after excluding outliers).

The empirical results show that past earnings, cash flows and accrual component of earnings can be used to predict future cash flows of Egyptian listed companies and cash flows have better predictive power than past earnings. Additionally, the cash flow model and the cash flow and accrual components of earnings model have better predictive power than the earnings model. The findings of testing the models in an out-of-sample period suggest that the cash flow model is a better predictor of future cash flows than the other models.

Keywords: Cash flow prediction, Operating Cash flow, Accrual, Earnings. 


\section{1- Introduction}

The main purpose of accounting is to provide financial information relating to the business units for users in order to assist decision-making process. Additionally, the purpose of accounting research is to evaluate the usefulness of accounting information for investors and other users. Financial statements are one of the most important sources of information that investors need while making investment-related decisions (Hadi, 2006).

The Financial Accounting Standards Board (FASB) stated that a primary objective of financial reporting is to provide information useful to market participants in assessing the amount and timing of future cash flows (e.g. SFAC No. 8). According to Barth et al. (2001) predicting future cash flows is fundamental in the equity valuation process. In addition, numerous studies suggested that one way the value relevance of earnings can be measured is through the ability of earnings to predict future cash flows (e.g. Dechow 1994; Finge1994).

Francis and Schipper (1991), stated that financial information is value relevant if it contains the variables used in a valuation model or assists in predicting those variables. They indicated that value relevance can be measured by the ability of earnings to predict future cash flows.

A firm's ability to generate cash flow affects the values of its securities. As a consequence, the Financial Accounting Standards Board (FASB) indicated that a primary objective of financial reporting is to provide information to help investors, creditors, and others to assess the amount and timing of prospective cash flows (FASB, 1978). Moreover, the FASB asserted that information about earnings and its components is generally more predictive of future cash flows than current cash flow (Barth et al., 2001). 
Thus, cash flow forecasting can be seen as a crucial component of the economic decisions. Furthermore, cash flows play an important role approximately in all decisions of groups such as securities analysts, creditors and directors. They are interested in assessing the future cash flow of the company so as to achieve an observable indicator of cash flows of corporations in the future. In other words, a general purpose of fundamental analysis is the forecasting of future cash flows of corporations (Staubus, 2004).

Future cash flow aggregation is a key to the valuation of a firm's securities. Whereas, the alternative valuation models used by both academics and financial analysts have majorly focused on the prediction of free cash flows (Copeland,1995).

Nevertheless, earnings occupy a central position in accounting, as it is on the accounting's summary measure of a firm's performance. Despite previous theoretical models that value cash flows, accounting earnings is widely used in share valuation and to measure performance in management and debt contracts (Dechow, 1998).

Net income is the profit that a company has earned for a period, while cash flow from operating activities measures among other things the cash going inand out during a company's day-to-day operations. Net income is the starting point in calculating cash flow from operating activities. However, both are important in determining the financial going concern of a company (Badertscher et el., 2007).

From a management point of view, the cash flow is taken into account as a vital power for the company so that whenever the company needs cash, the 
needed cash must be financed. In other words, it provides the firm with a fast to liquidate cash power as a security against market emergencies. Consequently, the company ability in creating and managing cash is important for the remaining and lasting its life (Sharma, 2001).

To forecast the cash flow as well as assessing the firm's value, investors need to form expectations about the economic factor for future periods, of which allows future cash flows generations. In addition to provide information regarding the transitory part of future cash flows unrelated to the economic factor (Barth et al., 2016).

A firm's ability to generate cash flow affects the value of its securities, so the ability to assess future cash flow is important for the investment community, both shareholders and creditors. While shareholders may be concerned with the stream of cash flows to perpetuity, many creditors are concerned solely the short-term cash-generating ability of a company (Yan, 2005).

Firm liquidity relates to the ability of a company to convert assets to cash. Liquidity is essential in periods of low earnings where the firm is unable to access capital markets and therefore serves as an important defense against market fluctuations and continues normal business operations (Anderson, 2002). Without sufficient liquidity, firms may also not be able to take advantage of potentially profitable investment opportunities, as a consequence, impact the long-term growth of the firm as well as its survival (Bond et al., 2003; Fazzari et al., 1988).

Cash is the blood stream of any business; hence, it is essential for managers to know how much cash has been generated from operating 
activities. Knowledge regarding the cash flow expectations from ongoing operating activities assist managers in the planning process, which may include tasks like future budgeting, future capital investments, hiring and operating expenses. It also reflects the firm's efficient use of resources, as steady cash flow is often largely associated with well managed company, profitability and efficient decision making (Bradbury, 2011). Thus, this information is valuable to not only managers but also investors and creditors.

Accountability, transparency and clear information about the cash flow stream generated from core business activities is part and parcel to good credit analysis. It is also noticeable that time of information availability can be seen critical, especially that it reflects the company's transparency and openness (Chang, 2003).

A key role of accrual accounting is to align a firm's cash flows and the economics of generating it, which provides detailed information regarding how the cash flow was firstly generated. This may include periods before and after the occurrence of the events of which generated this revenue in a shape of cash flow. Accruals recognized as assets and liabilities reflect this alignment and, as a result, reflect information about the firm's past and future cash flows (Barth et al., 2016).

Accrual is also globally recognized to be efficient, as it is fundamental to financial reporting. As the conceptual framework explains, accrual accounting depicts the effects of transactions and other events and circumstances on a firm's economic resources i.e. assets, and claims against those resources, liabilities and equity in the periods in which those effects 
occurred, even if the resulting cash receipts and payments occur in a different period (Barth et al., 2016) .

This is important because the conceptual framework expresses the belief that information about a firm's economic resources, claims, and changes in them, during a period provides a better basis for assessing the firm's past and future performance. Especially compared to information solely about cash receipts and payments during that period. Accruals are the mechanism by which current period cash flow is modified to create a more predictive performance measure, namely earnings. Thus, financial reporting has evolved to enhance performance measurements by using accruals to alter the timing of cash flow recognition in earnings (FASB, 2010).

Many analysts believe that cash flow from operations is a guarantee of better financial performance than net income. This is especially true, as it was found to be less subjective to distortion resulting from the different accounting practices (Dechow,1994). These claims have been empirically confirmed by DeFond and Hung (2003), who emphasized that financial analysts tend to issue cash flow forecasts for firms with different accounting choices.

The future cash flow used as the predictive measurement as it plays a vital role and is considered to be useful to the different users of accounting information including investors, creditors, financial analysts and other sectors such as investing, lending and other decision making (Bowen et al., 1986). Evidently, the measure of future cash flow accord with the main objective of financial reporting as stated out by accounting standards legislators, which aims in assisting users especially the stock investors in 
predicting inflow and outflow of cash and also estimating the value of the company (Holthausen et al., 2001).

\section{2- The Study objective}

The purpose of this study is to investigate the impact of accrual and cash

flow components to improve the predictive ability of earnings to forecastfuture cash flows.

\section{3- Significance of Study Problem}

The importance of this study is to empirically answer the above stated research question, the results may have significant implications to the following matters:

It may contribute to assess the cash flows of future cash flow of company so as to achieve an observable indicator of cash flows of corporations in the future.

It provides the characteristics of accruals-based and cash-based accounting data relating to future cash flows.

It provides the model which is having a greater predictive power in forecasting future cash flow for Egyptian listed companies in the Egyptian stock exchange except banks and financial institutions.

It may offer contributions to the reformation of policies and decisions about the what information should be provided to the general public taken by the Securities and Exchange Commission (SEC).

This research aims to provide a theoretical and practical framework for future research. 


\section{4- Literature Review and Research hypotheses.}

\subsection{Literature Review}

Most studies in cash flow prediction examine the relative usefulness of aggregate earnings and $\mathrm{CF}$ in forecasting future cash flows.

To date, research investigating the relevance of accounting data in predicting future cash flows has concentrated on the relative predicative ability of aggregate cash flow from operations. However, the role of earnings components (i.e., CF and accruals) in forecasting future cash flows is not fully understood.

The importance of cash flow prediction explained and the summary of the previous and recent empirical work related to the relative ability of cash flow from operation and earnings data in forecasting future cash flows presented.

Finger. (1994) demonstrated that Cash flow from operations is more powerful in short horizon. In long term horizon both earnings and cash flow

Dechow et al. (1998) proposed the first theoretical model using CF and working capital accruals to argue that earnings have higher predictive ability than cash flow for future cash flows. Their model implied earnings better predict future operating cash flows than did current operating cash flows.

Barth et al. (2001) provide the first evidence on the role of earnings components, particularly accrual components, in the forecast of future cash flows and demonstrated that disaggregating earnings into aggregate $\mathrm{CF}$ and major accrual components(i.e. changes in accounts receivable, accounts payable, inventory and the amounts of depreciation expense; amortization 
expense and the net of other accruals)significantly enhances the predictive ability of aggregate earnings compared to aggregate $\mathrm{CF}$ and earnings disaggregated into $\mathrm{CF}$ and total accruals.

Kim et al. (2005) investigated the ability of current earnings in forecasting future cash flow and reported the power of earnings in forecasting future cash flow has been increased.

Brochet et al. (2008) find that the mean and median contributions of accruals in terms of absolute prediction errors are smaller compared to CFO only when predicting aggregated CFO and free cash flows over one to eight quarters. While the differences are generally statistically significant, their magnitude is small; accruals reduce the median absolute prediction error from CFO alone by no more than $8 \%$ of the error. When predicting contemporaneous or next quarter market value of equity as a proxy for all (expected) future cash flows, accruals clearly contribute. Indeed, mean and median absolute prediction errors are smaller by more than 5\% of total assets when accruals are included as a predictor. These results show the importance of assessing the predictive ability of accruals for future cash flows by measuring the predicted variable over a sufficient long horizon.

Hollieet al. (2008) then decomposed the CF component of earnings into cash flows from sales, cash flow from cost of goods sold, cash flow from operating expenses and cash flows related to other revenue/expense items. They showed that estimated CF components provide incremental information over and above accrual components. That is, CF and accrual components together outperform. Barth et al.'s model which comprises aggregate CF and accrual components only. 
Lev et al., (2010) conclude that the usefulness of accounting estimates to investors is limited and provide suggestions for improving the usefulness of estimates, it also examine the contribution of accounting estimates embedded in accruals to the quality of financial information, as reflected by their usefulness in the prediction of enterprise cash flows and earnings.

Farshadfar et al., (2013) investigate whether the predictive ability of earnings is enhanced by accruals and CF components in forecasting future cash flows. The results also indicate that the components of $\mathrm{CF}$ and accruals individually contribute to the predictive ability of earnings, whereas aggregate CF and accrualsmask their information content.

Takhtaei et al., (2013) predicted future cash flow of Iranian firms and report different results. A study by Takhtae and Karimi (2013) find that earnings outperform cash flow from operations which support FASB assertion on the superiority of earnings in predicting future cash flows.

Mulenga et al., (2015)The overall findings of this study reported cash flow from operation provide a better predictive power of future cash flow from operations than earnings.

Barth et al., (2016) analysis of the model reveals that each accounting amount cash flow and accruals associated with the prior and next periods' cash flows has a different coefficient in valuation, forecasting future cash flow, and forecasting earnings. Each of these coefficients is a combination of a weight that reflects the information role the accounting amount plays and valuation and forecasting multiples that reflect differences in how that information is used in valuation and cash flow and earnings forecasting. 


\subsection{Hypothesis Development}

On the basic literature review, hypothesis are developed:

Several empirical studies had been confirmed that disaggregate earnings (operating cash flows and accruals) improve the predictive abilitty of earning on forecasting future cash flow (Finger1994, Barth 2001, Brochet 2008, Chenge 2008), .In contrast, according to (Dechow 1998, kim2005, Takhtaei 2013 ) the earning are more accurate forecasts of future operating cash flows than operating cash flow and accruals Therefore, the hypothesis in this research could be expressed as following:

H1: There is no difference between earnings, accruals and cash flow measures as predictors of future cash flows.

\section{5- The Empirical Study}

5.1. Models development and research variables

\subsubsection{Regression model.}

Based on theory and empirical findings in previous researches, regression model will be used to study the impact of operating cash flow and accruals components of earnings to improve the predictive ability of earning to forecast future cash flow.

CFOit $=\alpha 0+\alpha_{1}$ EARNit-1 $+\varepsilon_{\text {it }}$

CFOit $=\beta 0+\beta 1$ CFOit-1 $+\beta 2$ TACit-1 + Eit

Where:

CFoit: Cash flow from operation for firm $i$ in year $t$.

EARNit-1: Earnings before extraordinary and discontinuing items for 
firm $i$ in year $t-1$.

TACit-1: Total accruals for firm $i$ in year $t-1$.

Eit : Random Error.

\subsubsection{Variables definition and measurement:}

Dependent variable: cash flow from operation (CFo)

Cash flow from operating activities (CFO) is an accounting item that indicates the amount of money a company brings in from ongoing, regular business activities, such as manufacturing and selling goods or providing a service. Cash flow from operating activities does not include long-term capital or investment costs.

Measurement of the dependent variables

\begin{tabular}{|l|l|l|}
\hline Variable & Abbreviation & Operational Definition \\
\hline Operating cash flow & CFo & $\begin{array}{l}\text { Net cash flow from operating } \\
\text { activities less the accrual portion of } \\
\text { extraordinary items and } \\
\text { discontinued operations reported } \\
\text { on the statement of cash flows. }\end{array}$ \\
\hline
\end{tabular}

Cash flow from operating is a net cash received and cash paid from operations. It is also known as operating cash flow (OCF) or net cash from operating activities.

\section{Independent variable:}

Earnings (EARN): Earnings considered as a key measure in evaluation of company's performance and is an important factor for management of debt 
and debt contracts (Dechow et al., 1998). It is also used as key variable and plays important role in predicting firm's future cash flows (Greeberg et al., 1986)

Net income before extraordinary items and discontinued operations are presented on income statements(Barth et al.,2001).

Accruals:

Accruals are the non-cash component of earnings.Earnings can be disaggregated into cash flow and accruals.

Apart from cash from operations, the accrual has also been used as predictor variable of future cash flows among researchers and it is measured differently by various researchers. For example, Beisland (2011) used the following formula for accruals Accruals= Change in total current assets - Change in cash - Change in total current liabilities + Change in interest bearing-short term debt-Change in deferred taxes -depreciation and impairment. Others researchers mathematically calculated accruals by taking the difference between earnings and cash flow from operations (Barth et al.,2001; Al-Attar \& Hussain,2004).

Measurement of the independent variables

\begin{tabular}{|l|l|l|}
\hline Variable & Abbreviation & Operational Definition \\
\hline Earnings & EARN & $\begin{array}{l}\text { Income before extraordinary items } \\
\text { and discontinued operations. }\end{array}$ \\
\hline Total accruals & TAC & $\begin{array}{l}\text { Measured as earnings minus cash } \\
\text { flow from operations. }\end{array}$ \\
\hline
\end{tabular}




\subsection{Data description and descriptive statistics}

\subsubsection{Population and Sample selection}

The study population includes all Egyptian companies listed on the Egyptian stock exchange, after excluding Firms from banking industry and financial utility industry are excluded due to the special nature of their financial reports.

A random sample of 101 firms from $2012-2017$ is selected from 13 different sectors, to obtain 585 firm- year observations for each variable in the study. 18 firm - year observations are then eliminated, because they are detected as outliers. The study used 567 firm - year observations to study the predictive ability earnings, accruals and cash flow components of earnings to forecast future cash flows.

Table(1): Industry distribution of the sample.

\begin{tabular}{|c|c|c|c|c|c|c|c|}
\hline \multirow{3}{*}{ NU } & \multirow{3}{*}{ Sector } & \multicolumn{6}{|c|}{ Years and numbers of companies } \\
\hline & & 2012 & 2013 & 2014 & 2015 & 2016 & 2017 \\
\hline & & \multicolumn{3}{|c|}{ Nu of firmNu of firrNu of firm } & Nu of firms & Nu of firms & Nu of firms \\
\hline 1 & Telecommunication & 4 & 4 & 4 & 4 & 4 & 4 \\
\hline 2 & Media & 1 & 1 & 1 & 1 & 1 & 1 \\
\hline 3 & Food and beverage & 17 & 17 & 17 & 17 & 17 & 17 \\
\hline 4 & Construction and materia & 18 & 18 & 18 & 18 & 18 & 18 \\
\hline 5 & Technology & 3 & 3 & 3 & 3 & 3 & 3 \\
\hline 6 & $\begin{array}{l}\text { Industrial goods, service } \\
\text { and automobiles }\end{array}$ & 11 & 11 & 11 & 11 & 11 & 11 \\
\hline 7 & $\begin{array}{l}\text { Healthcare } \\
\text { pharmaceuticals }\end{array}$ & 8 & 8 & 8 & 8 & 8 & 8 \\
\hline 8 & Travel and leisure & 4 & 4 & 4 & 4 & 4 & 4 \\
\hline 9 & Real Estate & 11 & 11 & 11 & 11 & 11 & 11 \\
\hline 10 & Gas and petrol & 1 & 1 & 1 & 1 & 1 & 1 \\
\hline
\end{tabular}




\begin{tabular}{|l|l|l|l|l|l|l|l|}
\hline 11 & Chemicals & 5 & 5 & 5 & 5 & 5 & 5 \\
\hline 12 & $\begin{array}{l}\text { Personal and Hous } \\
\text { Products }\end{array}$ & 8 & 8 & 8 & 8 & 8 \\
\hline 13 & Basic Resources & 6 & 6 & 6 & 6 & 6 & 6 \\
\hline 14 & Retail & 2 & 2 & 2 & 2 & 2 & 2 \\
\hline Number of firms in sample & 99 & 99 & 99 & 99 & 99 & 99 \\
\hline Number of firms listed & 212 & 212 & 214 & 221 & 222 & 222 \\
\hline (-) Banks and Financial Service & 34 & 38 & 38 & 43 & 46 & 47 \\
\hline Number of nonfinancial firms & 178 & 174 & 176 & 178 & 176 & 175 \\
\hline Percentage of sample & $55.6 \%$ & $56.9 \%$ & $56.2 \%$ & $55.6 \%$ & $56.2 \%$ & $56.6 \%$ \\
\hline
\end{tabular}

5.2.2. Descriptive statistics and correlation analysis.

\subsubsection{Descriptive Statistics.}

Descriptive statistics for the variables used in the estimation equations are presented in table $(2)$;it is used to show the mean, standard deviation, maximum and minimum and to provide background information on the data used in the study.

Table (2) . Descriptive statistics for the sample

\begin{tabular}{|c|c|c|c|c|c|}
\hline variables & Mean & $\begin{array}{c}\text { Standard } \\
\text { deviation }\end{array}$ & Maximum & Minimum & (N) \\
\hline CFOit & .096 & 3.35 & 2.5 & -1.88 & 585 \\
\hline CFOit-1 & 1.05 & 3.39 & 2.5 & -1.88 & 585 \\
\hline EARNit-1 &, 057 & 2.38 & 1.43 & -2.86 & 585 \\
\hline TACit-1 & $\mathbf{- . 0 4 7}$ & $\mathbf{3 . 5 6}$ & 1.91 & $\mathbf{- 4 . 8 6}$ & $\mathbf{5 8 5}$ \\
\hline
\end{tabular}

Table NO (2) summarizes the descriptive statistics for theregression variables including: the dependent variable, operating cash flow andindependent variable, earnings, operating cash flows and accruals, which investigated in the empirical analysis of this study. The descriptive statistics include: mean, median, standard deviation, minimum values and 
maximum values. The number of observations are 585 during 6 years from 2012 to 2017.

The mean of CFOit (dependent variable) is .096 and falls between 1.88 and 2.5. The standard deviation is 3.35

The mean of CFOit-1(independent variable) is $\mathbf{1 . 0 5}$ and falls between -1.88 and 2.5. The standard deviation is 3.39

The mean of EARNit-1 (independent variable) is ,057and falls between -2.86 and 1.43. The standard deviation is 2,38 .

The mean of TACit-1 (independent variable) is -,047 and falls between -4.8 and 1.91. The standard deviation is 3.56

\subsubsection{Correlation Analysis}

Table (3) shows the Pearson correlation which is used to test the correlations between all variables of the study models. This table shows positive future cash flow and current cash flow, future cash flow and current earnings, current cash flow and current earnings. However, there is negative relation between future cash flow and current total accruals, current cash flow and current total accruals

Correlation

\begin{tabular}{c|rrrr} 
Probability & CFOIT & CFOIT_1 & EARNIT_1 & TACIT_1 \\
\hline CFOIT & 1.000000 & & & \\
& ---- & & & \\
CFOIT_1 & 0.656608 & 1.000000 & & \\
& 0.0000 & $-\cdots$ & & \\
EARNIT_1 & 0.282437 & 0.275894 & 1.000000 & \\
& 0.0000 & 0.0000 & $-\cdots--$ & \\
TACIT_1 & -0.436082 & -0.767096 & 0.404996 & 1.000000
\end{tabular}


The Pearson correlation between contemporaneous $\mathrm{CFO}$ and $\mathrm{E}(\mathrm{r}=\mathbf{0 . 2 8})$ indicates a positive relationship. A significant negative relationship exists between contemporaneous cash flows and accruals $(r=-0.43)$. Finally, the Pearson correlation between CFOt and CFOt-1 is 0.65, indicating a strong level of persistence (cross-sectionally) in the cash flow measure.

\subsection{Multiple regression model validity}

The study will use the multiple regression model to test the hypothesis and investigate the difference between earnings, accruals and cash flow components of earnings to predict future cash flows. Ordinary least squares (OLS) method is used to estimate the parameters of multiple regression model, because the estimates obtained by (OLS) are better and less biased (Ananey, 2011). To use OLS regression analysis in estimating the study models, the researcher should make sure that OLS assumptions are met, and these assumptions are:

\subsubsection{Normality of residuals}

The assumption states that the residual follows the normal distribution with zero mean and constant variance. This assumption is not necessary for the estimation of regression parameters because observation is more than 200 observations (Fidell and Tabachnick 2007), but it is necessary for the statistical inference namely hypotheses tests .To test the normality assumption the study uses Shapiro- wilk tests for normality of residuals . 
Model(1)

Table (4): Shapiro-Wilk test for normal data

\begin{tabular}{|l|l|l|l|}
\hline Variable & Observation & $\mathbf{Z}$ & Prob $>$ Z \\
\hline Residuals & $\mathbf{5 8 5}$ & $\mathbf{1 2 . 9 6 5}$ & $\mathbf{0 . 0 0 0}$ \\
\hline
\end{tabular}

In first model of this study the $p$ value of Shapiro-wilk test is $(z=12.965)$ and the test sig is less than the level of significance $5 \%$. So that the residual of regression is not normally distributed is accepted.

$\operatorname{Model}(2)$

Table (5): Shapiro-Wilk test for normal data

\begin{tabular}{|l|l|l|l|}
\hline Variable & Observation & $\mathbf{Z}$ & Prob $>\mathbf{Z}$ \\
\hline Residuals & $\mathbf{5 8 5}$ & $\mathbf{1 2 . 9 6 5}$ & $\mathbf{0 . 0 0 0}$ \\
\hline
\end{tabular}

In second model of this study the $p$ value of Shapiro-wilk test is $(z=$ 12.965) and the test sig is less than the level of significance $5 \%$. So that the residual of regression is not normally distributed is accepted.

\subsubsection{Multi-collinearity}

The second assumption of the (OLS) method is multi-collinearity, which means there is a perfect or exact linear relationship between some of independent variables of the regression model of the study. The variance inflation factors (VIF) will be checked for multi-collinearity, which indicates a linear relationship between the potential independent variables. As the degree of multi-collinearity increases, the estimated coefficients will become unstable as well as the standard errors. A VIF higher than 10 will lead to the conclusion that there is a multicollinearity (Gujarati, 2003).

The VIF for all variables in the study models are less than 10. Therefore, there is no multi-collinearity in the study model. 
Model (1)

The model one is simple regression model so, the multicollinearity is not issue.

Model (2)

Table (6): Variance inflation factors

\begin{tabular}{|l|l|l|}
\hline Variable & VIF & 1/VIF \\
\hline CFOit-1 & 2.43 & 0.411564 \\
\hline TACit-1 & 2.43 & 0.411564 \\
\hline
\end{tabular}

Mean VIF

2.43

4.3.3. Heteroscedasticity

The third assumption in (OLS) method is heteroscedasticity by using Breusch-Pagan / Cook-Weisberg test for heteroskedasticity and (white test) to test the assumption of heteroscedasticity, Heteroscedasticity occurs when the residuals have unequal variances (nonconstant variance).

Model (1)

Breusch-Pagan / Cook-Weisberg test for heteroskedasticity

Ho: Constant variance

Variables: fitted values of CFOit

$$
\operatorname{chi} 2(1)=6.60
$$

Prob $>$ chi $2=0.0102$

imtest,white

White's test for Ho: homoskedasticity

against Ha: unrestricted heteroskedasticity

$$
\operatorname{chi} 2(2)=24.20
$$

Prob $>$ chi $2=0.0000$ 
The results indicate that there is heteroscedasticity problem because the prob of chi 2 is less then $.05 \%$

Model (2)

Breusch-Pagan / Cook-Weisberg test for heteroskedasticity

Ho: Constant variance

Variables: fitted values of CFOit

$\operatorname{chi} 2(1)=546.65$

Prob $>$ chi $2=0.0000$

imtest,white

White's test for Ho: homoskedasticity

against Ha: unrestricted heteroskedasticity

$\operatorname{chi} 2(5)=167.54$

Prob $>$ chi2 $=0.0000$

The results indicate that there is heteroscedasticity problem because the prob of chi 2 is less than $.05 \%$.

\subsubsection{Autocorrelation}

The fourth assumption of the OLS method is autocorrelation, which means that there is a correlation between the members of series observations ordered in panel data. The study used Wooldridge test to indicate autocorrelation between observations.

\section{Model(1)}

The prob of Wooldridge statistic is .6461. Based on the sample size and the number of explanatory variables at the level of significant $5 \%$.

Accepting the null hypothesis states that there is no autocorrelation. As a result there is no autocorrelation in the research data. 
Model(2)

The Wooldridge statistic is .0179. Based on the sample size and the number of explanatory variables at the level of significant $5 \%$.

It means that there is an autocorrelation the model(2) data.

clustered robust standard errors are used to correct for both heteroscedasticity and autocorrelation (Hoechle, 2007; and Holzhacker et al., 2015). consequently, the results of study models can be relied on.

Summary of multiple regression assumptions

\begin{tabular}{|l|l|l|}
\hline Problems & Results Model (1) & Results Model (2) \\
\hline Normality & $\begin{array}{l}\text { the residuals are not } \\
\text { normally distributed }\end{array}$ & $\begin{array}{l}\text { the residuals are not } \\
\text { normally distributed }\end{array}$ \\
\hline Multi-collinearity & $\begin{array}{l}\text { The VIF for all variables in } \\
\text { the study models are less than } \\
\text { 10. Therefore, there is no } \\
\text { multi-collinearity in the study } \\
\text { model. }\end{array}$ & $\begin{array}{l}\text { The VIF for all variables } \\
\text { in the study models are } \\
\text { less than 10. Therefore, } \\
\text { there is no multi- } \\
\text { collinearity in the study } \\
\text { model. }\end{array}$ \\
\hline Heteroscedasticity & $\begin{array}{l}\text { There is heteroscedasticity } \\
\text { problem because the chi2 is } \\
\text { lessthen .05\% }\end{array}$ & $\begin{array}{l}\text { The results indicate that } \\
\text { there isheteroscedasticity } \\
\text { problem because the chi2 } \\
\text { is less than .05\% }\end{array}$ \\
\hline Autocorrelation & $\begin{array}{l}\text { There is no autocorrelation } \\
\text { problem }\end{array}$ & $\begin{array}{l}\text { There is autocorrelation } \\
\text { problem }\end{array}$ \\
\hline
\end{tabular}

Table (7). Hausman test result ( fixed effect V.S. random effect )

- FE vs. RE: Hausman test. The null hypothesis is that the random effects estimates and the fixed effects estimates are not significantly different. If the null isn't accepted, it is preferred to use FE rather than RE.Table (7) show the results of the preceding tests. 


\begin{tabular}{|c|c|c|c|c|c|}
\hline Test & $\begin{array}{c}\text { Test } \\
\text { objective }\end{array}$ & $\begin{array}{l}\text { Study } \\
\text { models }\end{array}$ & $\begin{array}{l}\text { Chi-Sq. } \\
\text { Statistic }\end{array}$ & $\begin{array}{c}P \text { - } \\
\text { value }\end{array}$ & $\begin{array}{c}\text { The relevant } \\
\text { model }\end{array}$ \\
\hline \multirow{2}{*}{ 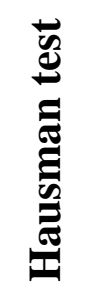 } & \multirow{2}{*}{ 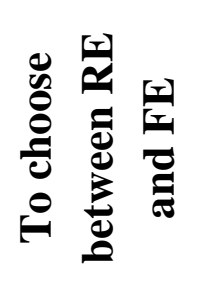 } & Model1 & 3.4632 & 0.062 & FE model \\
\hline & & Model2 & 266.53 & 0.000 & FE model \\
\hline
\end{tabular}

P. Value from Hausman test is less than .05 that confirms that fixed effect method should be used.

\section{Testing of Hypotheses}

\subsection{Regression results}

Statistical techniques are used to analyze the regression results and test the hypotheses to answer the research questions.

The multiple linear regression model results enable the testing of the impact of accrual and cash flow components of earnings to improve the predictive ability of earning to forecast future cash flow by the measurement of the relationship between the dependent variable operating cash flow and the independent variable earning in Model (1) and the relationship between the dependent variable operating cash flow and the independent variable accruals and previous operating cash flow in Model (2).

Previously it is evident that the most significant conditions to use the regression model and the absence of regression models estimated from any standard problems affect its results.

Depending on the program Eviews 9 to perform statistical analysis, the panel Data regression analysis was used to assess whether any explanatory variables had an effect on the dependent variable, and also to indicate the 
contribution rate of each variable to explain the relationship with the dependent variable, as follows:

Table ( 8): Regression results.

Model 1: The impact of aggregate earning on Operating cash flow

CFOit $=$ B0 + B $_{1}$ EARNit-1 $+\varepsilon_{i t}$

\begin{tabular}{|c|c|c|c|c|}
\hline \multicolumn{5}{|c|}{$\begin{array}{l}\text { Panel A: Summary of results for within-sample forecasting tests ( } 567 \text { firm- } \\
\text { years, 2012-2017) }\end{array}$} \\
\hline $\begin{array}{l}\text { Explanatory } \\
\text { variables }\end{array}$ & $\begin{array}{l}\text { Coefficient } \\
\text { (B) }\end{array}$ & $\begin{array}{l}\text { Std. } \\
\text { Error }\end{array}$ & t-test value & t-test sig. \\
\hline Constant & 46310101 & 6452748 & 7.176803 & 0.0000 \\
\hline EARNIT-1 & $\mathbf{0 . 2 3 9 1 8 2}$ & 0.112588 & 2.124407 & 0.0342 \\
\hline \multicolumn{5}{|c|}{$\begin{array}{l}* \text { Relation is significant at the } 0.10 \text { level } \\
* * \text { Relation is significant at the } 0.05 \text { level } \\
* * * \text { Relation is significant at the } 0.01 \text { level }\end{array}$} \\
\hline $\begin{array}{l}\text { R2 }=0.6741 \\
\text { Adjusted R2 } \\
\text { Prob(F-statis } \\
\text { F statistics= }\end{array}$ & $\begin{array}{l}606814 \\
=0.000000 \\
00540\end{array}$ & & & \\
\hline $\begin{array}{l}\text { Panel B: Sun } \\
\text { years, 2016-2 } \\
\text { Theil's U-sta } \\
\text { Bias proport } \\
\text { Variance pro } \\
\text { Covariance p }\end{array}$ & $\begin{array}{l}\text { ary of results } \\
\text { 7) Theil's U- } \\
\text { ic } 0.334068 \\
0.000889 \\
\text { rtion } 0.1378 \\
\text { portion } 0.861\end{array}$ & $\begin{array}{l}\text { out-of-san } \\
\text { stic }\end{array}$ & recasting te & 189 firm- \\
\hline
\end{tabular}

Model 2: The impact of disaggregate earning (operating cash flow and total accruals) on Operating cash flow

CFOit $=\beta 0+\beta 1$ CFOit-1 $+\beta 2$ TACit-1 + Eit 


\begin{tabular}{|c|c|c|c|c|}
\hline \multicolumn{5}{|c|}{$\begin{array}{l}\text { Panel A: Summary of results for within-sample forecasting tests (567 firm- } \\
\text { years, 2012-2017) }\end{array}$} \\
\hline $\begin{array}{l}\text { Explanatory } \\
\text { variables }\end{array}$ & $\begin{array}{l}\text { Coefficient } \\
\text { (B) }\end{array}$ & $\begin{array}{l}\text { Std. } \\
\text { Error }\end{array}$ & t-test value & t-test sig. \\
\hline Constant & 42778678 & 4864769 & 8.793568 & 0.0000 \\
\hline CFOIT1 & 0.170737 & 0.080822 & 2.112501 & 0.0352 \\
\hline TACIT1 & 0.164213 & 0.087278 & 1.881484 & 0.0605 \\
\hline \multicolumn{5}{|c|}{$\begin{array}{l}* \text { Relation is significant at the } 0.10 \text { level } \\
* * \text { Relation is significant at the } 0.05 \text { level } \\
* * * \text { Relation is significant at the } 0.01 \text { level }\end{array}$} \\
\hline \multicolumn{5}{|c|}{$\begin{array}{l}\mathrm{R} 2=.702898 \\
\text { Adjusted R2=.640685 } \\
\text { Prob(F-statistic) }=\mathbf{0 . 0 0 0 0 0 0} \\
\text { F statistics }=11.29815\end{array}$} \\
\hline \multicolumn{5}{|c|}{$\begin{array}{l}\text { Panel B: Summary of results for out-of-sa } \\
\text { years, 2016-2017) Theil's U-statistic } \\
\text { Theil's U-statistic } 0.317610 \\
\text { Bias proportion } 0.00000 \\
\text { Variance proportion } 0.123958 \\
\text { Covariance proportion } 0.876042\end{array}$} \\
\hline
\end{tabular}

\section{Vuong's Z-statistic}

$$
\begin{aligned}
& \text { Model (1) vs. Model (2) } \\
& \mathbf{t}=3.05 \\
& \text { pro=0.003 }
\end{aligned}
$$

$i$ and $t$ denote firm and year, respectively. CF is net cash flow from operating activities under the cash flow statement. EARN is earnings before extraordinary and discontinuing items. TAC is total accruals calculated as the deference between EARN and CF.

To assess the forecasting ability of the models, we first estimate the adjusted R2 for 2012-2017. Vuong's (1989) likelihood ratio test for model selection is 
then applied to test whether the explanatory powers of two competing models significantly diff er (Dechow, 1994). We use out-of-sample in addition to within-sample forecasting tests because a higher adjusted R2 does not necessarily represent a superior predictive ability (Watts and Leftwich, 1977). Accordingly, we employ Theil's U-statistic as a forecast error measure, as per Kim and Kross (2005) and Bandyopadhyay et al. (2010). In particular, we compare the forecast accuracy of aggregate and disaggregated earnings (models (1) through (2)) during the period 20122017. Theil's U-statistic is decomposed into bias, variance and covariance proportions. In a good prediction, the covariance proportion, which represents unsystematic errors, is greater than the bias and variance proportions. The bias proportion captures the systematic error, and the variance proportion measures the extent to which the fluctuations in the fitted series follow those in the actual series. Theil's U-statistic falls between zero and one, with values closer to zero signifying higher forecasting accuracy (Pindyck and Rubinfeld, 1998). The t-statistic is based on White's (1980) robust standard errors.The results of $T$-test are used to test the significant of each explanatory variable. The prob $F$ statistics are used to test the significance of the regression model. By comparing prob $F=0.000$ with level of significance $5 \%$, It is found that prob $\mathrm{F}$ is less than the level of significance $5 \%$. So that, the regression model is significant.

The first point to note is that there is evidence of the gains to the disaggregation of earnings data. Model 1 generates the lowest adjusted Rsquared values. The full sample models has an adjusted R-squared of $\mathbf{0 . 6 0 6 8 1 4}$ and $\mathbf{. 6 4 0 6 8 5}$ for models (1) and (2) respectively which means that 
independent variables explain $60.68 \%$ \& $64.06 \%$ of the variation in operating cash flow in model (1) and model (2) respectively.

When earnings are disaggregated into cash flows and aggregate accruals, the adjusted $R$-squared values increase and this increase is statistically significant in all cases as indicated by the Vuong statistics.

The Vuong test statistic examines the explanatory power of a model, with respect to the previous model, i.e. model 2 versus model 1. A significant positive Z-statistic shows that the first model is rejected in favour of the second model.

Theil's U-statistic is a forecast error statistic that lies between zero and one, where one shows the worst fit. In a good prediction, the bias and variance proportions of Theil's U-statistic are smaller than its covariance proportion. so, disaggregating earnings into operating cash flow and total accrual is more useful in predicting future cash flows than earnings alone.

\section{Conclusion}

Using panel data, The study investigate whether the ability of earnings in forecasting future cash flows is enhanced by accruals and CFo. In particular, we compare the predictive ability of earnings(Model1) against operating cash flow and total accruals (Model2)

We analyse a sample of 567 firm-years representing 97 Egyptian listed companies over 2012-2017. We conduct within-sample tests over 2012-2017 and out-of-sample tests over 2016-2017. We compare the adjusted $R 2$ of the OLS regression estimates with White's (1980) correction for heteroscedasticity during the within-sample period. We use Theil's U-static with its three components (bias, variance and covariance proportion) to compare out-of-sample forecasting accuracy. Our study provides evidence 
that CFo and total accrual are more useful than aggregate earnings. The study concludes that historical operating cash flows, accruals and earnings are significant in predicting future cash flows. It is however established that their predictive abilities differs and that historical operating cash flow and accruals have superior predictive ability on future operating cash flows than historical earning. Earning therefore has the least predictive ability on future operating cash flows.

\section{Implications}

This research can be a helpful for investors because they need to estimate the cash return from their investment in the capital markets. Also, the decision makers are interested in a firm's cash flows because they expect that current cash flows may affect their future cash flows. In addition, cash flows are expected to be a natural alternative performance indicator to evaluate a firm's performance because earnings are not informative when they are transitory and extreme and cash flows are already available to be used in cash flow statements. The investors also consider cash flow a sustainable performance measure for a firm's valuation. The findings of this study inform shareholders that they can depend on current operating cash flow and accruals to forecast future cash flow than earnings.

\section{Future Research}

Future studies can examine and compare the relative predictive abilities of disaggregated accruals (accounts receivable, accounts payable, and inventory) and disaggregated operating cash flows components (such as cash received from customers, cash paid to suppliers and etc.). 


\section{References}

Al-Attar, A. and S. Hussain. 2004. Corporate data and future cash flow. Journal of Business Finance and Accounting 31 (7/8): 861-903.

Ananey, M. 2011. Statistical and econometric analysis for economical relationship : using SPSS. 3rd edition, Faculty of commerce, Zagazig university. Egypt. [Translated]

Badertscher, B., D. Collins, and T. Lys. 2007. Earnings management and the predictive ability of accruals with respect to future cash flows. Working paper. University of Notre Dame, University of Iowa, Northwestern University.

Barth, M. E., D. P. Cram, and K. K. Nelson. 2001. Accruals and the prediction of future cash flows. The Accounting Review 76 (1): 27-58.

Barth, M. E., G. Clinch, and D. Israeli. 2016. What do accruals tell us about future cash flows? Review of Accounting Studies 21 (3): 768-807.

Bond, S., J. Elston., J. Mairesse, and B. Mulkay. 2003. Financial Factors and Investment in Belgium, France, Germany and the United Kingdom: A Comparison Using Company Panel Data. The Review of Economics and Statistics 85 (1): 153-165.

Bowen, R., D. Burgstahler, and L. Daley. 1986. Evidence on the relationships between earnings and various measures of cash flow. The Accounting Review 61 (October): 713-725.

Bradbury, M. 2011. Direct or indirect cash flow statements? Australian Accounting Review 21: 124-130.

Brochet, F., S. Nam, and J. Ronen. 2008. The role of accruals in predicting future cash flows and stock returns. Working paper, Harvard Business School. 
Cheng, C. S. A, and S. S. M. Yang. 2003. The incremental information content of earnings and cash flows from operations affected by their extremity. Journal of Business Finance and Accounting 30 (1): 73-116.

Cheng, A. and D. Hollie. 2008. Do core and non-core cash flows from operations persist differentially in predicting future cash flows? Review of Quantitative Finance and Accounting 31 (1): 29-53.

Copeland, T., T. Koller, and J. Murrin. 1995. Valuation: measuring and managing the value of

Dechow, P. M., S .P .Kothari, and R. L. Watts. 1998.The relation between earnings and cash flows. Journal of Accounting and Economics 25 (2): 133-168.

Farshadfar, $\mathrm{S}$.and R.Monem. 2013.The usefulness of operating cash flow and accrual components in improving the predictive ability of earnings. Accounting and Finance 53 (4): 1061-1082.

Farshadfar, S.and R.Monem. 2013. Further evidence on the usefulness of direct method cash flow components for forecasting future cash flows. The International Journal of Accounting .

Fazzari, M., G. Hubbard., B. Petersen., A. Blinder. and J. Poterba. 1988. Financing Constraints and Corporate Investment. Brookings Papers on Economic Activity 1988: 141-206.

Financial Accounting Standards Board (FASB). 1978.Statement of Financial Accounting

Concepts No. 1: Objectives of Financial Reporting by Business Enterprises. Stamford, CT: FASB.

Financial Accounting Standards Board (FASB). 1987.Statement of Financial Accounting

Standards No. 95: Statement of Cash Flows. Stamford, CT: FASB. 
Financial Accounting Standards Board (FASB). 2010. Statement of Financial Accounting Concepts No. 8: Conceptual Framework for Financial Reporting, Chapter 1, the Objective of General Purpose Financial Reporting, Norwalk, CT, September.

Finger, C.A. 1994.The ability of earnings to predict future earnings and cash flows. Journal of Accounting Research 32(2): 210-23.

Francis, J., and K. Schipper. 1991. Have Financial Statements Lost Their Relevance? Journal of Accounting Research 37 (2): 319-52.

Greenberg, R.R., G. L. Johnson, and K. Ramesh. 1986. Earnings versus cash flows as a predictor of future cash flow measures. Journal of Accounting, Auditing and Finance 1:266-77.

Gujarati, D.N.2003. Basic Econometrics. 4th edition. New York: McGrawHill.

Hadi, M. M. 2006. The Value-Relevance of Income Levels and Components Reported. International Research Journal of Finance and Economics 4: 133-142.

Hoechle, D. 2007. Robust standard errors for panel regression with crosssectionaldependence. The Stata Journal 7(3): 281 - 312.

Holthausen, R. W., and R. L. Watts. 2001. The Relevance of the valuerelevance literature for financial accounting standard setting. Journal of Accounting \& Economics 31(3): 75.

Holzhacker, M., R. Krishnan, and M. D.Mahlendorf. (2015). The impact of changes in regulation on cost behavior. Contemporary Accounting Research 32(2): 534-566.

Kim, M. and W. Kross. 2005. The ability of earnings to predict future operating cash flows has been increasing - not decreasing. Journal of Accounting Research 43 (5): 753-80. 
Lev, B., L. Siyi., and T. Sougiannis. 2005. Accounting estimates: pervasive, yet of questionable use. Working paper.New York University.

Mulenga, M. J. 2015. The Relative Ability of Earnings and Cash Flow from Operations in Predicting Future Cash Flows: Evidence from India. International Journal of Accounting and Financial Reporting 5 (2): 2162-3082.

Pindyck, R. S., and D. L. Rubinfeld, 1998, Econometric Models and Economic Forecasts. McGraw Hill, New York, NY.

Sharma, D. 2001. The role of cash flow information in predicting corporate failure: The state of the literature. Managerial Finance 27( 4):3-28.

Tabachnick, B. G., and L.S. Fidell, 2007. Using multivariate statistics. Allyn\& Bacon/Pearson Education.

Takhtaei, N. and H. Karimi. 2013. Relative ability of earnings data and cash flow in predicting future cash flows. International Journal of Accounting and Financial Reporting 3 (1): 2162-3082.

Vuong, Q. H. 1989. Likelihood ratio tests for model selection and non-nested hypotheses, Econometrica 57: 307-333.

Watts, R. L., and R. W. Leftwich. 1977. The time series of annual accounting earnings. Journal of Accounting Research 15: 253-271.

White, H. 1980. A heteroscedasticisity-consistent covariance matrix estimator and a direct test for heteroscedasiticy, Econometrica 48: 817-838.

Yan, P. W. 2005. Accruals and the prediction of future cash flows in Hong Kong. Hong Kong Baptist University. 
ياخل التنبؤ بالتدفق النقدي في عدد من القرارات الاقتصادية ، لا سيما في مجال الاستثمار. حيث قدمت الأبحاث السابقة التي أجريت في الولايات المتحدة عدم اتساق في نتائج التحقيق في البيانات المحاسبية والتدفقات النقدية وبيانات المحاسبة على أساس الاستحقاق في التنبؤ بالتدفقات النقدية المستقبلية. تم الكثف عن عدد قليل من الأبحاث التي تتناول التتبؤ بالتدفق النقدي في السياق المصري. يهدف هذا البحث إلى اختبار القدرة المحاسبية للأرباح مقابل التدققات النقدية والمستحقات على التنبؤ

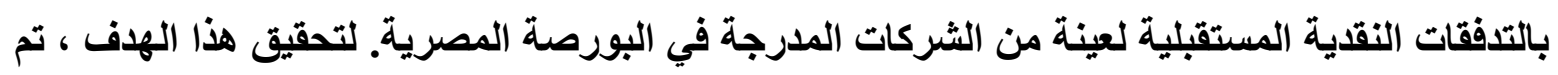
جمع عينة من 102 شركة من 14 قطاعًا مختلفًا من عام 2012 إلى 2017 (585 ملاحظة بعد استبعاد (القيم المتطرفة).

تظهر النتائج التجريبية أنه يمكن استخدام الأرباح السابقة والتدفقات النقدية ومكونات الأرباح

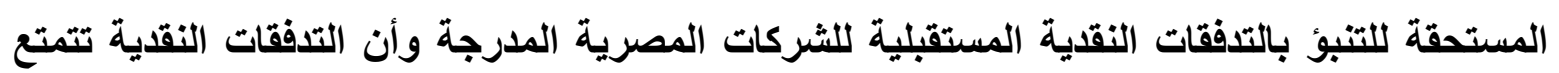

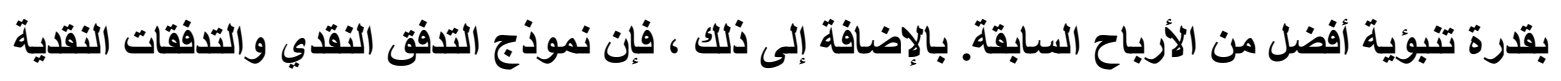

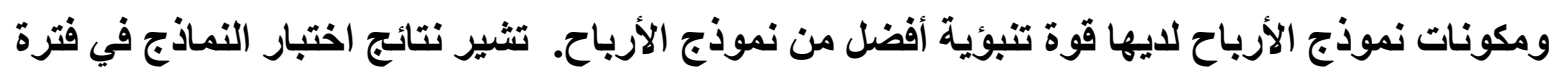

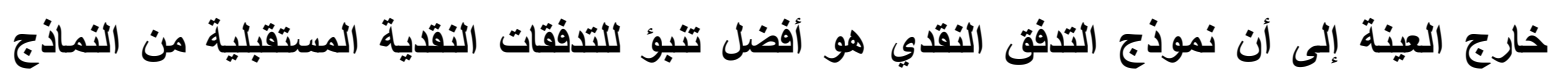
الأخرى.

الكلمات المفتاحية: التنبؤ بالتدفق النقدي ، التدفق النقدي التثغيلي ، الاستحقاق ، الأرباح. 